\title{
Two paternal genomes are compatible with dopaminergic in vitro and in vivo differentiation
}

\author{
SOON WON CHOI', SIGRID ECKARDT², RUHEL AHMAD ${ }^{1}$, WANJA WOLBER ${ }^{3}$, K. JOHN MCLAUGHLIN², \\ ANNA-LEENA SIRÉN ${ }^{3}$ and ALBRECHT M. MÜLLER ${ }^{*, 1}$ \\ ${ }^{1} \mathrm{MSZ}$ and Center for Experimental Molecular Medicine (ZEMM), University of Wuerzburg, Wuerzburg, Germany, \\ ${ }^{2}$ Nationwide Childrens Research Institute, Columbus, Ohio, USA and \\ ${ }^{3}$ Department of Neurosurgery, University of Wuerzburg, Wuerzburg, Germany
}

\begin{abstract}
Patient derived stem cell-based therapies are considered a future treatment option for Parkinson's disease, a chronic and progressive brain neurodegenerative disorder characterized by depletion of dopaminergic neurons in the basal ganglia. While many aspects of the in vitro and in vivo differentiation potential of uniparental parthenogenetic (PG) and gynogenetic (GG) embryonic stem (ES) cells of several species have been studied, the capacity of androgenetic (AG) ES cells to develop into neuronal subtypes remains unclear. Here, we investigated the potential of murine AG ES cells to undergo dopaminergic differentiation both via directed in vitro differentiation, and in vivo, in ES cell-chimeric E12.5 and E16.5 brains. We show that similar to normal ( $N$; developed from a zygote with maternal and paternal genomes) ES cells, AG cells generated dopaminergic neurons in vitro and in E12.5 and E16.5 chimeric brains following blastocyst injection. Expression of brain-specific imprinted genes was maintained in AG and normal dopaminergic cell cultures. Our results indicate that AG ES cells have dopaminergic differentiation potential in vitro and in vivo. This contrasts with previous reports of limited neural in vivo differentiation of AG cells in later brain development, and suggests that AG ES cells could be therapeutically relevant for future cellular replacement strategies for brain disease.
\end{abstract}

KEY WORDS: embryonic stem cell, androgenetic, differentiation, dopaminergic neuron

\section{Introduction}

Parkinson's disease is a degenerative neurological disorder with characteristic motor symptoms that are caused by a loss of dopamine-producing cells in the substantia nigra (Jankovic, 2008; Olanow and Tatton, 1999). Clinical studies using striatal transplantation of human fetal ventral mesenchephalic tissue grafts have already demonstrated proof-of-concept for dopaminergic cell therapy in Parkinson's disease. In these early studies, graft tissue consisting of postmitotic dopaminergic neuroblasts survived and restored the striatal dopamine release and provided clear clinical benefits for selected patients (Deierborg et al., 2008; Lindvall and Kokaia, 2009). The future of this regenerative approach has been questioned after disappointing results in the follow-up trials that failed to show sufficient clinical improvements and revealed side effects potentially induced by the grafts (Deierborg et al., 2008; Lindvall and Kokaia, 2009). Since graft availability and standardization will likely limit the use of human fetal tissue for a cell replacement therapy in Parkinson's disease, several approaches to produce dopaminergic neurons from neural stem cells have been initiated. However, the generation of sufficient numbers of functional dopaminergic neurons from primary cultures of fetal, neonatal or adult neural tissues is not yet possible with the current methods. Differentiating ES cell cultures represent a potential cell source for cell replacement therapies (Parish and Arenas, 2007; Sasai, 2002).

Several protocols have succeeded to generate ES cell differentiation systems for efficient neural induction and in the production of a wide range of neural subtypes including ES cell-derived dopaminergic neurons (Barberi et al., 2003; Bibel et al., 2007). ES cell-derived neurons of numerous species have been successfully tested in rodent and primate models of Parkinson's disease

Abbreviations used in this paper: AG, androgenetic; ES cell, embryonic stem cell; GG, gynogenetic; N, biparental; PG, parthenogenetic.

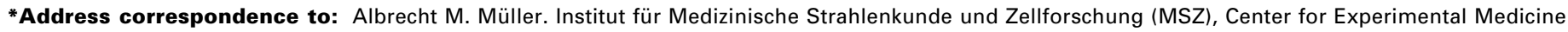
(ZEMM), University of Würzburg, Zinklesweg 10, 97078 Würzburg, Germany. Fax: +49-931-201-45146. e-mail: albrecht.mueller@mail.uni-wuerzburg.de
} 
(Lindvall and Kokaia, 2009; Takagi et al., 2005). ES cell-derived dopaminergic neurons showed electrophysiological and functional properties of midbrain dopaminergic cells (Kim et al., 2002). Importantly, ES cell-derived dopaminergic neurons restored behavioral function in animal models of Parkinson's disease (Bjorklund etal., 2002; Cibelli etal., 2002; Hedlund and Perlmann, 2009; Maxwell and Li, 2005; Rodriguez-Gomez et al., 2007; Toriumi et al., 2009; Yang et al., 2008). An additional benefit of ES cells is that the genome of these cells can be efficiently manipulated to direct lineage specification and function (Draper and Nagy, 2007; Menendez et al., 2005; Prelle et al., 2002).

A
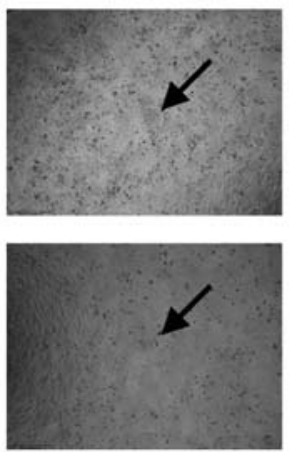

B
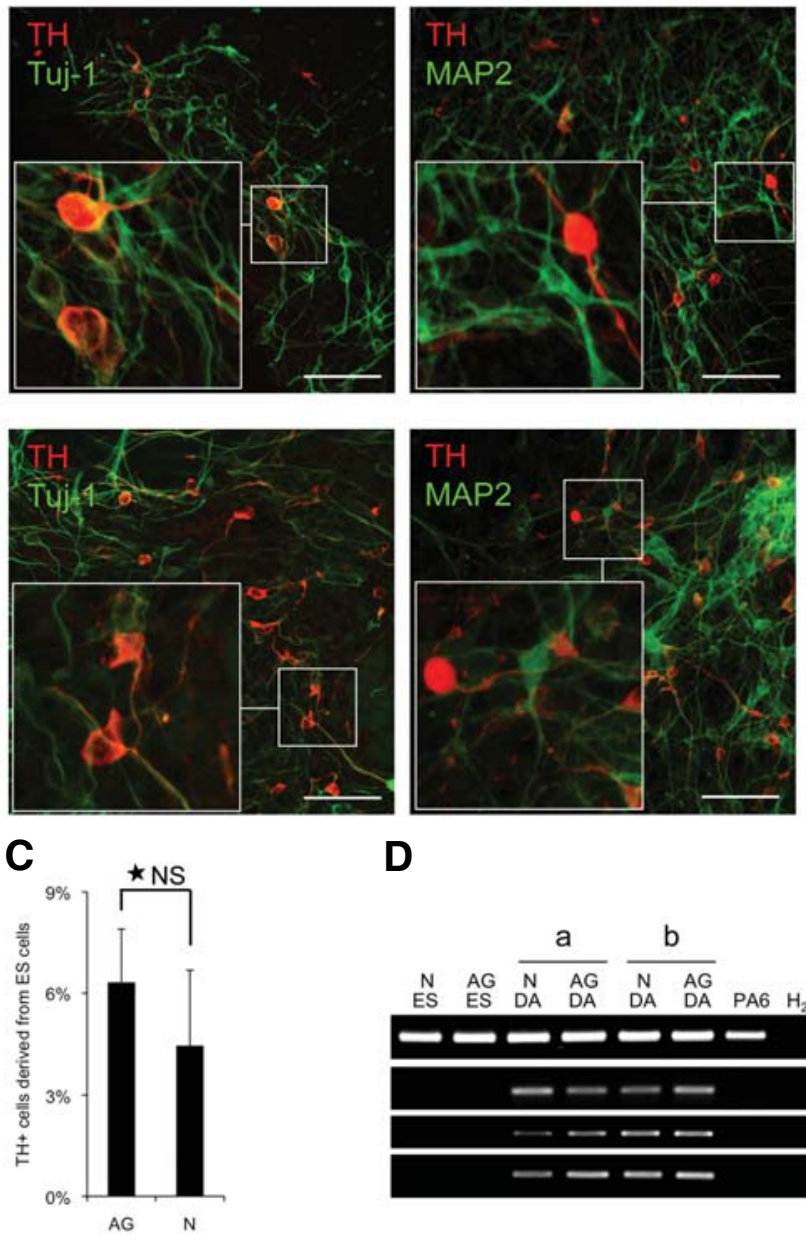

day 5
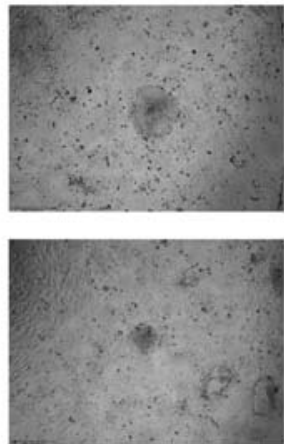

day 7
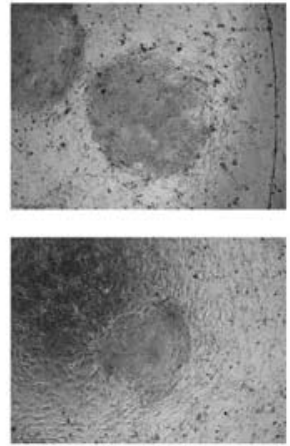

In mammals, embryos with only maternally (PG, GG)- or paternally $(A G)$-derived genomes do not develop past early postimplantation stages due to the consequences of genomic imprinting. Maternal and paternal genomes are functionally nonredundant due to differential DNA methylation and transcription from paternal and maternal alleles (Solter, 2006). Abnormal levels of parent-of-origin-specific gene expression of imprinted genes during development are associated with a limited postimplantation viability of uniparental embryos (Barton et al., 1984; Cattanach and Kirk, 1985; McGrath and Solter, 1984; Surani et al., 1984). Despite the compromized in vivo developmental potential of uniparental embryos, diploid uniparental $A G$ and $P G / G G$ embryos develop to the blastocyst stage and can be used for the derivation of ES cell lines. Uniparental ES cell lines have been derived in mouse (Mann et al., 1990; Robertson et al., 1983) and primate species including humans (Cibelli et al., 2002; Revazova etal., 2007). Mouse uniparental ES cell lines are pluripotent and contribute to multi-lineage post-implantation development, including the germ line (Allen et al., 1994; Narasimha et al., 1997). While PG ES cell chimeras can survive postnatally with substantial contribution of ES cells (Sturm et al., 1994), AG ES cell chimeras typically exhibit severe defects and high lethality during fetal and postnatal stages (Mann et al., 1990; Narasimha et al., 1997). However, similar to ES cells derived from biparental $(\mathrm{N})$ embryos, uniparental ES cells generate ecto-, meso-, and endodermal cell lineages in cell cultures including neural progenitor/stem cells and engrafting hematopoietic stem cells (Dinger et al., 2008; Eckardt et al., 2008; Eckardt et al., 2007; Lengerke et al., 2007; Teramura et al., 2009).

We consider the analysis of AG ES cells relevant for two reasons: 1.) basic research: so far it is unclear which types of tissue stem cells can develop in the ab-

Fig. 1. In vitro dopaminergic differentiation of androgenetic (AG) and normal (N) ES cells. (A) PA6 coculture-induced dopaminergic differentiation of $A G$ (top) and N (bottom) ES cells. Time-lapse, phase-contrast images illus-
D

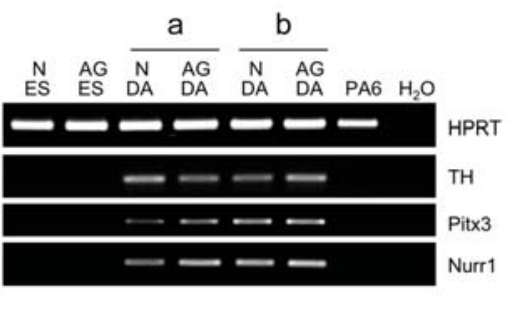
trate the morphological changes in ES cell colonies growing on PA6 stromal cells. Arrows indicate an ES cell-derived colony. 4x magnification. (B) AG (top) and N (bottom) ES cell-derived neurons cultured for 2 weeks were stained with TH/Tuj-1, TH/MAP2 and TH/Synapsin-1. Confocal images of a representative analysis are shown. Scale bars: $25 \mu \mathrm{m}$. (C) Frequencies of $\mathrm{TH}^{+}$cells among eGFP+ $E S$ cell derivatives in $A G$ and $N$ cultures are given. Biological replica $(n)=3$ for parts $(A-C)$. ${ }^{*} N S$ : not significant ( $p=0.098$ ). (D) RT-PCR analysis for the expression of TH, Pitx3 and Nurr1 in undifferentiated AG or N ES cells, in PA6 stroma cell cultures of $N$ or AG ES cells and in PA6 stromal cells. Analysis of 2 independent differentiations $(a, b)$ are revealed. Shown is a representative analysis. 
sence of a maternal genome; 2.) tissue regeneration: PG- or GG-based cell replacement strategies do only cover fertile-aged females but not males. Thus uniparental strategies for the male population should be equally considered. Due to the severe phenotypes of AG ES cell chimeras AG ES cells have so far not been analyzed as extensively. Here, we show that murine AG and N ES cells do not differ in their differentiation potential in vitro in dopaminergic differentiation cultures and in vivo in fetal brain development upon blastocyst injection. Based on the analysis of brain-specific imprinted genes, differentiation into dopaminergic neurons is therefore not limited by paternal-only gene expression.

\section{Results}

\section{Neural and dopaminergic in vitro differentia- tion of androgenetic ES cells}

To assess the dopaminergic in vitro differentiation potential of $A G$ in comparison to N ES cells, we seeded $A G$ and $N$ ES cells in a coculture-based differentiation system for selective generation of dopaminergic neurons using mouse stromal cells (PA6 cells) as a feeder cell layer (Barberi et al., 2003). PA6 is a bone marrow-derived stromal cell line that is capable of supporting early hematopoietic and B-lineage progenitor cells (Nishikawa et al., 1988). More recent reports described the capability of PA6 cells to induce dopaminergic differentiation from ES cells in the presence of specific midbrain patterning and differentiation factors (Hermann et al., 2006; Kawasaki et al., 2000). We plated undifferentiated AG and N ES cells on PA6 stromal cells at low density. Sequential exposure to midbrain patterning and differentiation factors FGF8, $\mathrm{SHH}$, bFGF, and $\mathrm{SHH}$ was subsequently used to favor dopaminergic phenotypic specification during the coculture period (Fig. 1A). After a total differentiation period of 14 days, cells were immunostained for neuron-specific Tuj-1 (class III beta-tubulin), MAP2 (microtubule associated protein 2), for the dopaminergic neuron-specific marker tyrosine hydroxylase $(\mathrm{TH})$, and for the presynaptic vesicle protein Synapsin-1. As shown in Fig. 1B both $\mathrm{AG}$ and $\mathrm{N}$ cells stain positive for $\mathrm{TH} / \mathrm{Tuj}-1, \mathrm{TH} /$ MAP2 and TH/Synapsin-1 indicating that AG simi-
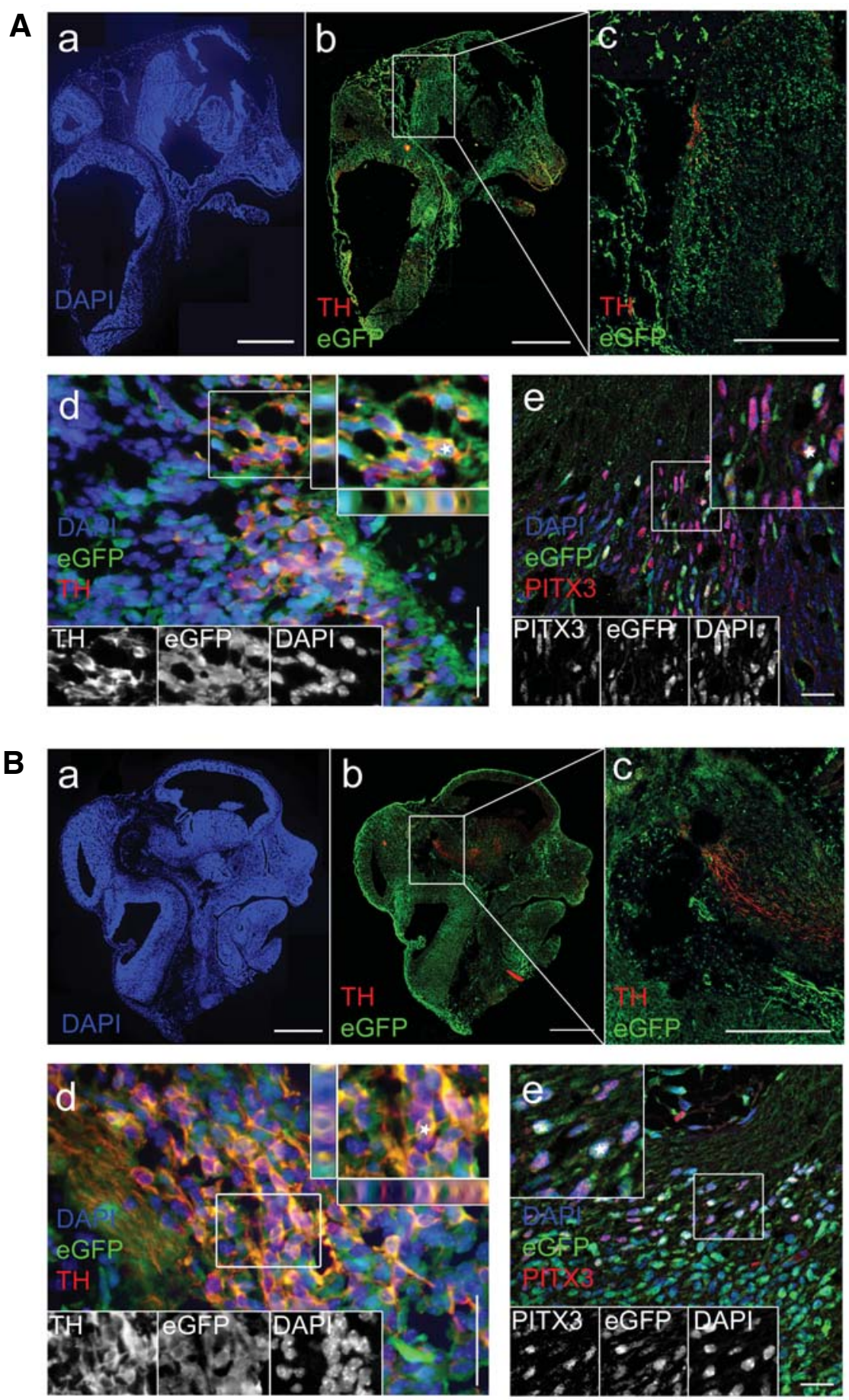

Fig. 2. In vivo differentiation of $\mathbf{A G}$ and $\mathbf{N}$ cells in $\mathbf{E} 12.5$ chimeric brains upon blastocyst injection. Following blastocyst injection of $A G$ or $N$ ES cells donor cells were analyzed in E 12.5 chimeric brains. (A) Immunostaining of cryosections of an AG ES cell-chimeric brain. (a) A representative sample shows DAPI staining of a sagittal section of an AG chimeric head (image combined from 13 individual pictures). (b) An overlay of anti-eGFP (donor cells, green) and anti-TH-specific (red) immunostainings is shown. A mid-brain region is marked. (c) Magnification of the mid-brain region. (d) Shown are overlays of red (TH; dopaminergic cells), green (anti-eGFP; ES cell-derived cells) and blue signals (DAPl; nuclei). Rectangle (top center) indicates area that was further analyzed by z-stack analysis. Insert (top right) shows a $50 \mu \mathrm{m} x$-y layer and orthogonal view in the $\mathrm{z}$ direction of $10 \mu \mathrm{m}$ cryosections to confirm signal colocalization. ${ }^{*}$ marks signal colocalization. Single color channels of the marked area (top center) are shown (bottom).(e) Overlays of red (PITX3; dopaminergic cells), green (anti-eGFP; ES cell-derived cells) and blue signals (DAPl; nuclei). Also z-stack analysis (upper right) and single color channels of a marked area are shown (bottom). Images shown in panels (a-d) were taken by a BioZero microscope, images in (e) came from a confocal microscope. $n=3$. (B) Immunostaining of representative sagittal cryosections from a N chimeric E12.5 brain. Overview shown in (a,b) were combined from 16 individual images. Panels are as described in (A). Scale bars: (a,b) $2 \mathrm{~mm}$; (c) $1 \mathrm{~mm}$; (d) $50 \mu \mathrm{m}$ and (e) $20 \mu \mathrm{m}$. 
lar to $\mathrm{N}$ ES cells can generate cells that immunophenotypically resemble dopaminergic neurons. $\mathrm{AG}$ and $\mathrm{N}$ cocultures generated similar frequencies of $\mathrm{TH}^{+}$cells $\left(\mathrm{TH}^{+} \mathrm{AG}\right.$ cells: $6.3 \pm 1.6 \% ; \mathrm{TH}^{+} \mathrm{N}$ cells: $4.5 \pm$ $2.2 \%$ ) (Fig. 1C). Morphological presence of Synapsin-1 positive puncta was detected in both $A G$ and $N$ ES cultures (Fig. 1B, right panels) indicating the ability of $A G$ and $\mathrm{N}$ derived dopaminergic neurons to form synaptic terminals.

To further define the cell types derived in the coculture system, we evaluated dopaminergic gene expression in $A G$ and $N$ ES-derived neurons. In contrast to $N$ and $A G$ ES cells as well as PA6 feeder cells, PA6 cultures of $N$ and AG dopaminergic neurons from two independent experiments exhibited expression of the dopaminergic-specific transcripts $\mathrm{TH}$, paired-like homeodomain transcription factor 3 (PITX3) and nuclear receptor-related 1 (Nurr1) (Fig. 1D). Together the data support the view that dopaminergic cells can be generated from AG and N ES cells in vitro.

\section{Neural and dopaminergic differentiation of androge- netic ES cells in chimeric animals}

To study the capacity of AG ES cells to participate in neural development within a developing embryo, we generated chimeric embryos by blastocyst injection of eGFP positive AG and, as a control, N ES cells. We identified and isolated chimeric embryos both at E12.5 and E16.5, and ascertained distribution and immunophenotype of GFP positive ES cell derived cells in sagittal sections of chimeric brains. Consistent with previous observations (Mann et al., 1990), the frequency of dead or absorbed embryos increased from E12.5 to E16.5 for AG ES cell-chimeric embryos ((Dinger et al., 2008) and data not shown). With increasing fetal age, ES cell contribution was lower in surviving AG chimeras compared to $\mathrm{N}$ chimeras (Table 1).

In E12.5 chimeric brains, TH- and PITX3-expressing cells of ES cell origin were present in the developing substantia nigra (Fig. 2). We further detected TH- and PITX3-positive ES cell derivatives in the ventral tegmental cell groups in E16.5 chimeric brains (Fig. 3). Z-stack analysis confirmed signal colocalization of eGFP and the dopaminergic markers TH and PITX3 (Fig. 2 and Fig. 3). Although donor chimerism varied between animals, we observed corresponding frequencies of eGFP/TH or eGFP/PITX3 double positive cells in AG and N chimeric brains, respectively (Table 1 ). This indicates that $A G$ and $\mathrm{N}$ cells generate with similar frequencies $\mathrm{ES}$ cell-derived dopaminergic neurons in chimeric E12.5 and E16.5 brains.

\section{Imprinted gene expression during neuronal differen- tiation of androgenetic ES cells}

To assess imprinting in dopaminergic cultures we analyzed gene expression of imprinted genes that are expressed in the developing brain by quantitative RTPCR. From a panel of brain-specific imprinted genes previously tested for expression in AG neurons, we restricted this analysis to genes not expressed in PA6
A
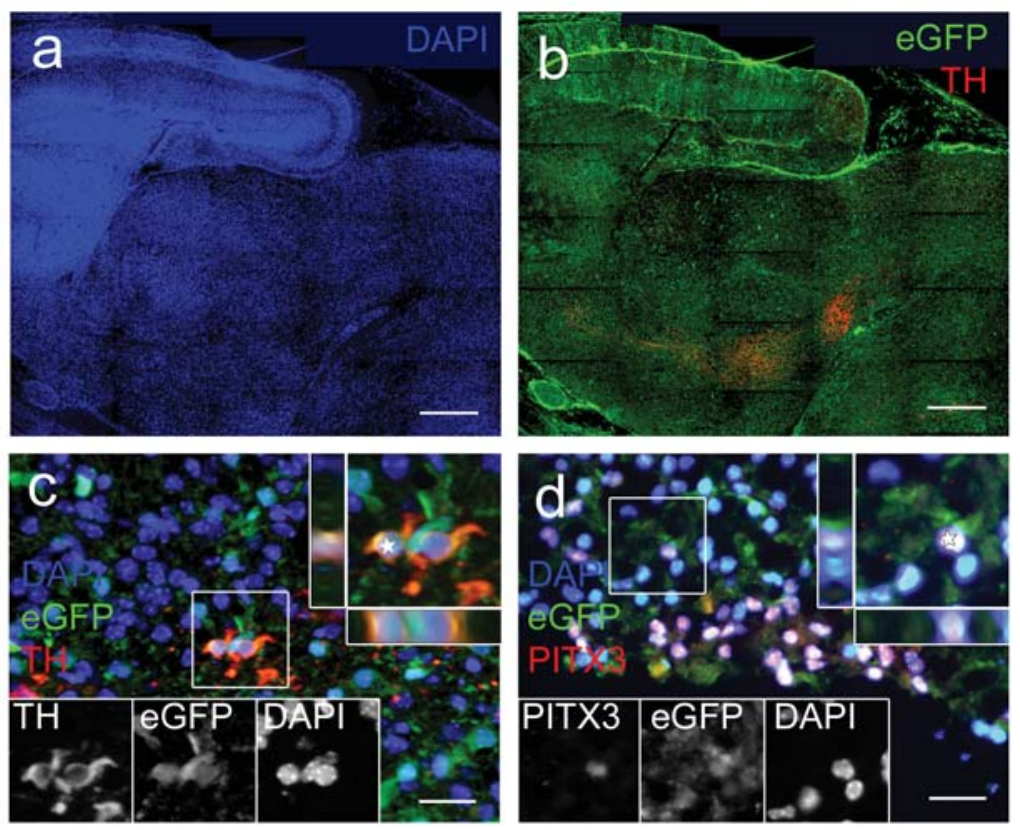

B
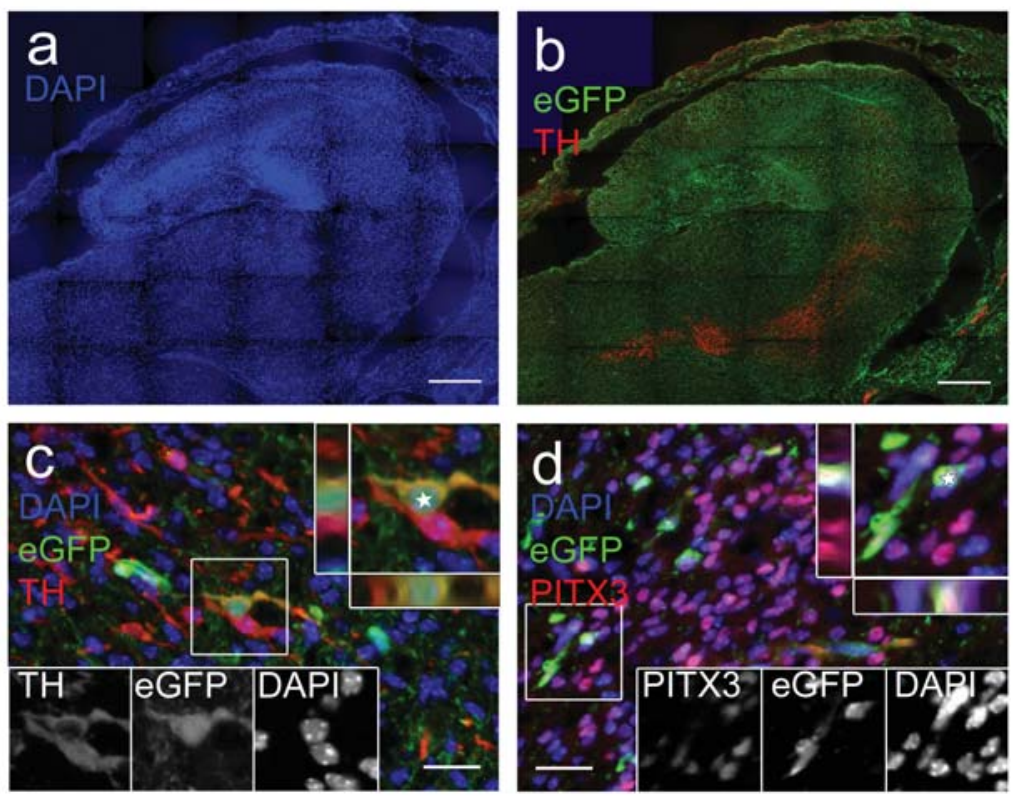

Fig. 3. Androgenetic (AG) and normal (N) donor cells were analyzed in E16.5 chimeric brains. (A) Immunostainings of a representative AG ES cell-chimeric midbrain. (a) ADAPI staining of a sagittal section (image combined from 28 individual photographs) is shown. (b) Anti-eGFP (green) and anti-TH-specific (red) immune stainings of the area as shown in (a) is revealed. (c) Overlays showing TH-, eGFP-and

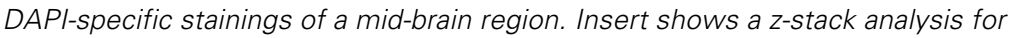
TH/eGFP signal colocalization (upper right). In addition higher magnifications of a marked region displayed in single color channels are displayed (bottom). (d) Shown is an overlay of green (anti-eGFP), red (PITX3; dopaminergic cells), and blue signals (DAPl; nuclei). Inserts show a z-stack analysis and single color channels for signal colocalization. * marks TH/eGFP or PITX3/eGFP signal colocalization, respectively. Images were taken by a BioZero microscope. (B) Immunostaining of representative sagittal cryosections from a normal chimeric $E 16.5$ brain. Overview shown in panels $(a, b)$ were combined from 35 individual images. Panels are as described in (A). Scale bars: (a,b) $2 \mathrm{~mm}$; (c,d) $25 \mu \mathrm{m}$. 


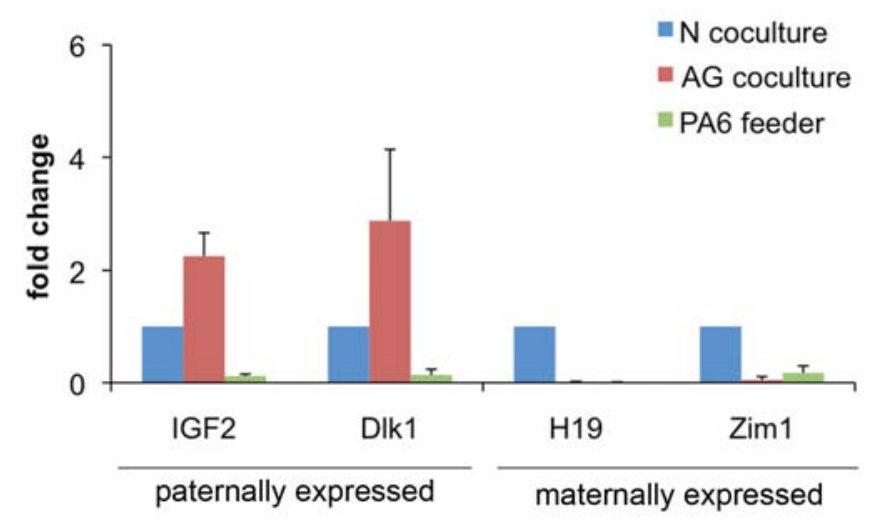

Fig. 4. Analysis for the expression of imprinted brain genes after in vitro dopaminergic differentiation of androgenetic (AG) and normal (N) ES cells. Relative expression of imprinted genes was compared in $N$ and AG ES cell-derived dopaminergic neurons in PA6 cocultures after two weeks of differentiation. Shown are quantitative RT-PCR data from representative batches of cocultures. The relative expression represents the fold change of gene expression in $A G$ to $N$ cells. Fold change was calculated by the $2^{\Delta C t}$ method. Expression levels of $N$ cells were set to 1 . In brain, IGF2 and DIk1 are preferentially paternally expressed, and Zim1, and $\mathrm{H} 19$ are preferentially maternally expressed. $n=3$.

stromal cells (Dinger et al., 2008). As shown in Fig. 4 the paternally expressed IGF2 and DIk1 genes exhibited higher levels of expression in $\mathrm{AG}$ compared to $\mathrm{N}$ dopaminergic neural cultures, while the maternal expressed $\mathrm{H} 19$ and $\mathrm{Zim} 1$ genes were not detected or are poorly expressed. This indicates that these imprinted genes maintain their parent-of-origin-specific gene expression bias in AG ES cell-derived dopaminergic neurons.

\section{Discussion}

Parkinson's disease is the most common degenerative neurological movement disorder and results primarily from the loss of dopaminergic neurons in the substantia nigra. Although effective symptomatic therapies are available, no proven neuro-restorative therapies have been established to date. In this study we report that uniparental AG ES cells are capable of differentiating into dopaminergic neurons in vitro and in vivo, similar to N ES cells.

Uniparental ES cells are one of several pluripotent cell types that could be a source of tissue for regenerative therapies for brain disease, along with $\mathrm{N}$ embryo-derived ES cells, induced pluripotent stem (iPS cells), and directly reprogrammed neural cells
(Eckardt et al., 2008; Vierbuchen et al., 2010; Yamanaka, 2007). Despite their similarity, these cell types are distinct in their origin (maternal or paternal gamete- only versus both parental genomes for uniparental versus N ES cells, factor-reprogrammed versus germ line reprogrammed for iPS versus all ES cell types), with consequences on epigenetic status (Chin et al., 2009; Deng et al., 2009; Doi et al., 2009; Sato et al., 2010) and potentially, differentiation capacity. For example, the neural differentiation capacity of the currently available iPS cell lines is variable and far less efficient than that of ES cells (Hu et al., 2010). For murine uniparental ES cells of both maternal and paternal origin, differentiation into transplantable hematopoietic derivatives has been demonstrated (Eckardt et al., 2007), suggesting that at least for this tissue type, potential effects of genomic imprinting are not consequential. Here, we show that the presence of two paternal genomes in AG ES cells is compatible with dopaminergic differentiation.

It has been recognized for some time that as a result of imprinting the two parental genomes are functionally not equivalent. In about $1 \%$ of the genes one of the two alleles is partially or completely switched off (Barton et al., 1984; McGrath and Solter, 1984). The decision to silence a particular allele depends on the germ line (paternal or maternal) from which the allele was inherited. Further analyses on the cellular consequences of imprinted gene expression have revealed that maternal and paternal genomes have opposite influences on proliferation, cell-cycle length, senescence, and tumor formation (Hernandez et al., 2003). There is increasing evidence that imprinted gene function affects brain development and behavior (Wilkinson et al., 2007).

The literature reports that upon blastocyst injection AG donor cell contribution to chimeras decreases during development (Barton et al., 1991). This phenomenon has been interpreted as a selective elimination process of AG cells (Fundele et al., 1989), however, the precise reasons for the decline of AG donor cell frequencies remains unclear. It has been estimated that $10 \%$ of AG cell contribution in chimeras leads to embryonic lethality (Narasimha et al., 1997), and higher levels AG ES cell contribution to late gestation chimeras are associated with severe defects and lethality (Mann et al., 1990). In our analyses we observed that AG ES cells, as previously reported for N and PG ES cells (Kim et al., 2002; Sanchez-Pernaute et al., 2008), generated dopaminergic neurons in vitro and in vivo. The frequencies of dopaminergic cells were similar in cultures and transplant recipients of AG and $\mathrm{N}$ cells. The apparent similar neural in vitro and in vivo activity of $A G$ and $N E S$ cells is surprising considering previous observations of substantial cell autonomous differences between the

TABLE 1

\section{FREQUENCIES OF TH+ AND PITX3+ DONOR CELLS IN AG AND NORMAL CHIMERIC E12.5 AND E16.5 BRAINS}

\begin{tabular}{|c|c|c|c|c|c|c|c|c|c|}
\hline \multirow[b]{2}{*}{ Days of gestation } & \multicolumn{6}{|c|}{12.5} & \multicolumn{3}{|c|}{16.5} \\
\hline & AG-2 & AG-3 & AG-4 & $\mathrm{N}-5$ & $\mathrm{~N}-8$ & $\mathrm{~N}-9$ & AG-b & AG-C & $\mathrm{N}-\mathbf{b}$ \\
\hline Donor cells* in midbrain & $\begin{array}{c}76.1 \% \\
761 / 1000\end{array}$ & $\begin{array}{c}53.5 \% \\
535 / 1000\end{array}$ & $\begin{array}{c}24.7 \% \\
247 / 1000\end{array}$ & $\begin{array}{c}86.5 \% \\
865 / 1000\end{array}$ & $\begin{array}{c}70 \% \\
700 / 1000\end{array}$ & $\begin{array}{c}58.1 \% \\
581 / 1000\end{array}$ & $\begin{array}{c}24.4 \% \\
163 / 669\end{array}$ & $\begin{array}{c}24 \% \\
191 / 797\end{array}$ & $\begin{array}{c}12 \% \\
69 / 574\end{array}$ \\
\hline TH-positive donor cells ${ }^{\star \star}$ & $\begin{array}{c}60.5 \% \\
150 / 248\end{array}$ & $\begin{array}{c}32.5 \% \\
108 / 332\end{array}$ & $\begin{array}{l}23.6 \% \\
41 / 174\end{array}$ & $\begin{array}{c}72.0 \% \\
126 / 175\end{array}$ & $\begin{array}{c}65.9 \% \\
112 / 170\end{array}$ & $\begin{array}{c}39.3 \% \\
103 / 262\end{array}$ & $\begin{array}{l}18.8 \% \\
39 / 207\end{array}$ & $\begin{array}{l}35.3 \% \\
72 / 204\end{array}$ & $\begin{array}{l}3.1 \% \\
5 / 162\end{array}$ \\
\hline PITX3-positive donor cells ${ }^{\star *}$ & $\begin{array}{c}56.9 \% \\
202 / 355\end{array}$ & $\begin{array}{c}39.2 \% \\
129 / 329\end{array}$ & $\begin{array}{l}25.1 \% \\
48 / 191\end{array}$ & $\begin{array}{c}68.0 \% \\
168 / 244\end{array}$ & $\begin{array}{c}65.4 \% \\
121 / 185\end{array}$ & $\begin{array}{c}39.7 \% \\
105 / 264\end{array}$ & $\begin{array}{l}34.4 \% \\
52 / 151\end{array}$ & $\begin{array}{l}35.8 \% \\
71 / 198\end{array}$ & $\begin{array}{c}8.9 \% \\
27 / 303\end{array}$ \\
\hline
\end{tabular}

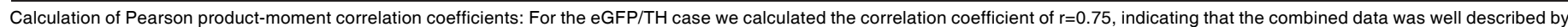

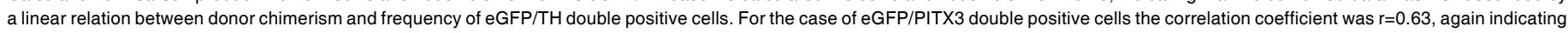
a linear relation. ${ }^{*}$ ) eGFP ${ }^{+}$cells / DAPI ${ }^{+}$cells. ${ }^{*}$ ) eGFP ${ }^{+}$cells $/ \mathrm{TH}^{+}$or $\mathrm{PITX}^{+}$cells. 
neural differentiation potential of $A G$ and $P G$ cells in developmental chimeras produced either by morula aggregation or inner cell mass injection into blastocysts (Keverne et al., 1996). In these studies, AG cells contributed preferentially to hypothalamic structures and lesser to the cortex while PG/GG cells engrafted substantially to the cortex, hippocampus and striatum but not to the hypothalamic structures.

Recently, it has been reported that during dopaminergic differentiation of human ES cells a specific region of the genome located on chromosome $11 \mathrm{p} 15.5$ becomes transcriptionally highly activated (Freed et al., 2008). As this region contains the paternally expressed /GF2 and the maternally expressed $H 19$ genes, it has been proposed that the H19-GF2 imprinting region is involved in the differentiation of ES cells into neuronal precursors and/or to dopaminergic neurons. Our results show that during dopaminergic differentiation of AG ES cells, a parent of origin specific expression bias is maintained for the imprinted /GF2 and H19 genes. Despite this unbalanced gene expression, AG like N cells generate dopaminergic neurons in vitro and in vivo, suggesting that a deregulation of /GF2and H19expression due to a lack of the maternal allele does not interfere with dopaminergic development.

The apparently similar in vitro and in vivo dopaminergic potential of $\mathrm{AG}$ and $\mathrm{N}$ cells in the present study is paralleled by the comparable neuronal and glial differentiation potential of $A G$ and N ES cells (Dinger et al., 2008; Okabe et al., 1996). Likewise, hematopoietic potential of the AG and $\mathrm{N}$ cells does not differ in vitro or in vivo (Eckardt et al., 2007). This suggests that, the differentiation potential of uniparental ES cells is less restricted in vitro or in blastocyst injection chimeras than that of entirely AGderived embryos. These surprising observations could either indicate that imprinting does not play a crucial role for the development of adult-type stem cells or that from the starting ES cell cultures only cells that show a relaxation of critical imprinted genes get selected. Alternatively, uniparental cells may develop other compensatory mechanisms. Indeed earlier analyses revealed that the expression of selected imprinted genes was relaxed in differentiating AG cell cultures adapting hematopoietic or neural cell fates (Dinger et al., 2008; Eckardt et al., 2007).

Numerous tumors are associated with the preferential loss of parental chromosomal regions. Examples include rhabdomyosarcoma (maternal chromosome 11p15.5) (Scrable et al., 1989), neuroblastoma (maternal chromosome 1 p36 or paternal chromosome 2) (Caron et al., 1993), and acute myeloblastic leukemia (paternal chromosome 7) (Katz et al., 1992). These observations suggest an involvement of imprinted genes in tumor-initiation or progression processes. Our analyses of chimeric E12.5 and E16.5 fetuses did not show signs of tumor formation indicating that AG chimeras are not more tumor-prone than N ES chimeras. This is in line with our earlier observation of no tumor formation in uniparental HSC transplant recipients or chimeras that developed upon blastocyst injections of PG/GG or AG ES cells (Eckardt et al., 2007). Our next perspective is to show whether a Parkinson's disease mouse model can be cured by transplantation of AG ES cell-derived dopaminergic neurons (Chiba et al., 2008; RodriguezGomez et al., 2007; Toriumi et al., 2009; Yang et al., 2008).

In summary we have shown that AG like $N$ ES cells can differentiate in vitro and in vivo in a blastocyst transplantation paradigm into dopaminergic neurons. AG cells are interesting cell systems to study the involvement of imprinting on tissue stem cell generation.

\section{Materials and Methods}

\section{ES cell culture}

$\mathrm{AG}$ and $\mathrm{N} \mathrm{eGFP}+$ murine ES cells ( $2 \mathrm{AG}$ cell lines and $2 \mathrm{~N}$ cell lines (Eckardt et al., 2007)) were cultured on inactivated primary murine embryonic fibroblasts (MEF) in DMEM high glucose (PAA Laboratories, Cölbe, Germany) supplemented with $15 \%$ ES cell-tested Fetal Calf Serum (FCS) (PAA), leukemia inhibitory factor (LIF)-conditioned medium, $1 \%$ Non Essential Amino Acids (PAA), Penicillin (100 U/mL) / Streptomycin (100 U/mL) (PAA), $2 \mathrm{mM} \mathrm{L-glutamine} \mathrm{(PAA),} 1 \mathrm{mM}$ sodium pyruvate (PAA) and $0.1 \mathrm{mM} \beta$-mercaptoethanol (Sigma-Aldrich, Schnelldorf, Germany) as previously described (Dinger et al., 2008). Medium was changed every day. For passage of ES cells, medium was removed, cells were washed with PBS and incubated with trypsin/EDTA (PAA). After 5 minutes, the reaction was stopped by adding medium/10 $\%$ FCS. Cells were collected, washed, resuspended and replated on fresh MEF feeder cells.

\section{Neural in vitro differentiation}

ES cells were differentiated into dopaminergic neurons using a coculture system with stromal cells as previously described (Barberi et al., 2003). Briefly, ES cells were placed on gelatin-coated plates $(0.1 \%$ in PBS; Sigma-Aldrich) for 30 minutes at $37^{\circ} \mathrm{C}$ to allow separation of MEFs and ES cells. For differentiation, a single cell suspension of ES cells was plated at a density of 100 cells $/ \mathrm{cm}^{2}$ on inactivated PA6 stromal cells and cultured for up to 14 days at $37^{\circ} \mathrm{C}, 5 \% \mathrm{CO}_{2}$ and $4 \% \mathrm{O}_{2}$. Culture medium was changed every second day after day 3 of culture. From seeding to day 8 , cells were cultured in serum replacement medium (SRM; DMEM supplemented with $15 \%$ Knockout $^{\mathrm{TM}}$ Serum Replacement (Invitrogen, Karlsruhe, Germany), $2 \mathrm{mM}$ glutamine and $10 \mu \mathrm{M} \beta$-mercaptoethanol). On days 5 and 7 , SRM was supplemented with $200 \mathrm{ng} / \mathrm{mL} \mathrm{SHH}$ and $100 \mathrm{ng} / \mathrm{mL}$ FGF8. From day 8 onwards, cells were cultured in N3 medium, supplemented with SHH, FGF8 and $50 \mathrm{ng} / \mathrm{mL}$ bFGF on day 8 and 10 , and with $20 \mathrm{ng} / \mathrm{mL}$ BDNF and $200 \mu \mathrm{M}$ ascorbic acid (Sigma-Aldrich) after day 11. All growth factors were purchased from PeproTech (Hamburg, Germany). Passage numbers of ES cells used for in vitro differentiation and transplantation experiments ranged from passages $20-40$.

\section{Immunostaining of cultured cells}

For multilabel fluorescent imaging using a SP5 Confocal Microscope (Leica, Wetzlar, Germany) cells grown on coverslips were fixed in $4 \%$ formaldehyde, permeabilized in $0.5 \%$ Triton- $X$ and stained with the following antibodies: rabbit anti-TH (1:500; Sigma-Aldrich), mouse/rabbit anti-Synapsin 1 (1:1000; SynapticSystems, Göttingen, Germany), mouse anti-Tuj-1 (1:1000) and mouse anti-MAP2 (1:500; Chemicon, Schwalbach, Germany), chicken anti-eGFP (1:500; Abcam, Cambridge, UK), and Cy2 (Chemicon), Cy3 and DyLight 649 (Dianova, Hamburg, Germany) labeled secondary antibodies (all in a dilution of 1:500). DAPI-Moviol was used as a mounting medium and for fluorescent counterstaining of nuclei.

\section{Analysis of imprinted brain gene expression using quantitative RT-} PCR

Total RNA was isolated from cultured cells by using peqGOLD RNAPure $^{\mathrm{TM}}$ (peqLab Biotechnologie, Göttingen, Germany). Before generation of cDNA, RNA preparations were treated with DNase I (Ambion, Applied Biosystems, Foster City, USA). RNA was reverse-transcribed into cDNA using M-MLV reverse transcriptase (Invitrogen). RT-PCR reactions were performed and quantified using a Rotor-Gene ${ }^{\mathrm{TM}} 3000$ (Corbett Life Science, LTF Labortechnologie, Wasserburg, Germany) and ABsolute ${ }^{T M}$ QPCR SYBR ${ }^{\circledR}$ Green Mix (ABgene, Hamburg, Germany). The relative gene expression levels were calculated with the $2^{\Delta C t}$ 
method. The $\Delta \mathrm{Ct}$-values indicate a difference of $\mathrm{Ct}$-values between reference gene and target gene. The housekeeping gene $\beta$-actin was used for the reference gene. The expression level of a target gene in $\mathrm{N}$ cells were set to 1 in order to determine differences of the target gene expression in AG cells. The primer sequences used were:

$\beta$-actin f: 5'-GATATCGCTGCGCTGGTCGTC-3'

\section{r: 5'-ACGCAGCTCATTGTAGAAGGTGTGG-3'}

Dlk1 f: 5'-TGTCAATGGAGTCTGCAAGG-3'

r: 5'-AGGGAGAACCATTGATCACG-3'

H19 f: 5'-CATGTCTGGGCCTTTGAA-3'

r: 5'-TTGGCTCCAGGATGATGT-3'

IGF2 f: 5'-CTAAGACTTGGATCCCAGAACC-3'

r: 5'-GTTCTTCTCCTTGGGTTCTTTC-3'

$\operatorname{Zim} 1$ f: 5'-GAGAAGCCGTACTGCTGTCA-3'

r: 5'-CTTGCACCGGTACCTGGAGT-3'.

\section{Generation of chimeric embryos by blastocyst injection}

Blastocyst injection was performed as described (Dinger et al., 2008). Briefly, to obtain blastocysts for the injection of ES cells, $6-8$ week old female NMRI mice were superovulated by intraperitoneal injection of 10 units pregnant mare's serum (PMSG), followed 48 hours later by an injection of 10 units human chorionic gonadotropin (hCG) (both Intervet, Unterschleißheim, Germany), caged with stud males and checked for vaginal plugs the next morning. The day of finding the plug was designated day 0.5 days post coitum (dpc). At $3.5 \mathrm{dpc}$, pregnant mice were sacrificed, ovaries and oviducts were removed and transferred into M16 medium (Sigma-Aldrich). Blastocysts were flushed from the oviducts and kept 1 to 2 hours in M2 medium (Sigma-Aldrich) prior to the injection of ES cells. To induce pseudopregnancy in recipient foster animals, $6-8$ week old female NMRI mice were mated with vasectomized NMRI males of proven sterility. ES cells as a single cell suspension were prepared in M2 medium prior to blastocyst injection.

\section{Immunohistochemistry of E12.5 and E16.5 brain cryosections}

For cryosections, whole E12.5 and E16.5 embryo heads were isolated and fixed for 12 hours in PBS/ $4 \%$ paraformaldehyde (Sigma-Aldrich). Following fixation, tissues were kept in PBS/ $16 \%$ glucose (Applichem), embedded in TissueTek O.C.T. (Sakura Finetek, Heppenheim, Germany) and frozen at $-80^{\circ} \mathrm{C} .10 \mu \mathrm{m}$ sagittal brain sections were stained with primary chicken antibody against eGFP (Abcam) and with secondary Cy2-conjugated goat anti-chicken IgY (Abcam). For neuronal cell staining, primary rabbit antibody against TH (dilution 1:1000; Sigma-Aldrich) or primary rabbit antibody against PITX3 (dilution 1:500; Zymed, Carlsbad, USA) and secondary Cy3-conjugated goat anti-Rabbit IgG (Chemicon) were used. Nuclei were counterstained with DAPI (Sigma-Aldrich). For analysis of co-localization of green and red signals, Z-stacks were taken using a BioZero microscope (400x magnification) (Keyence, Neu-Isenburg, Germany), yielding $X Y$ pictures and orthogonal $X Z$ and $Y Z$ projections of Z-stacks. In addition, a Leica SP5 Confocal Microscope was used. For intranuclear staining, tissue slices were microwaved for 6 minutes in 10 $\mathrm{mM}$ citrate buffer ( $\mathrm{pH}$ 6.0) for antigen retrieval.

\section{Quantification of eGFP+ ES cell-derived cell-contribution in E12.5 and E16.5 chimeric brains}

To quantify the contribution of eGFP ${ }^{+}$ES cell-derived cells in the midbrain, sagittal brain sections were stained using primary chicken antibody against eGFP (Abcam) and with secondary Cy2-conjugated goat anti-chicken IgY (Abcam) and DAPI. The percentage of eGFP ${ }^{+}$cells was determined by counting the numbers of DAPI-stained nuclei and the numbers of eGFP ${ }^{+}$cells in 3 representative $100 \mu \mathrm{m} \times 100 \mu \mathrm{m}$ squares per brain. The slides were analyzed by a blinded investigator.

\section{Acknowledgements}

We thank N. Adrian Leu for performing the ES cell injections and Doris Heim for expert cryosectioning and immunohistochemistry. We thank
Christoph F. Uhlemann for statistics. This work was supported by the Deutsche Forschungsgemeinschaft Research Training Group (GRK1048 "Molecular basis of organ development in vertebrates" to AMM).

\section{References}

ALLEN, N.D., BARTON, S.C., HILTON, K., NORRIS, M.L. and SURANI, M.A (1994). A functional analysis of imprinting in parthenogenetic embryonic stem cells. Development 120: 1473-1482.

BARBERI, T., KLIVENYI, P., CALINGASAN, N.Y., LEE, H., KAWAMATA, H., LOONAM, K., PERRIER, A.L., BRUSES, J., RUBIO, M.E., TOPF, N. et al. (2003). Neural subtype specification of fertilization and nuclear transfer embryonic stem cells and application in parkinsonian mice. Nat Biotechno/21: 12001207.

BARTON, S.C., FERGUSON-SMITH, A.C., FUNDELE, R. and SURANI, M.A. (1991). Influence of paternally imprinted genes on development. Development 113: 679-687.

BARTON, S.C., SURANI, M.A. and NORRIS, M.L. (1984). Role of paternal and maternal genomes in mouse development. Nature 311: 374-376.

BIBEL, M., RICHTER, J., LACROIX, E. and BARDE, Y.A. (2007). Generation of a defined and uniform population of CNS progenitors and neurons from mouse embryonic stem cells. Nat Protoc 2: 1034-1043.

BJORKLUND, L.M., SANCHEZ-PERNAUTE, R., CHUNG, S., ANDERSSON, T., CHEN, I.Y., MCNAUGHT, K.S., BROWNELL, A.L., JENKINS, B.G., WAHLESTEDT, C., KIM, K.S. et al. (2002). Embryonic stem cells develop into functional dopaminergic neurons after transplantation in a Parkinson rat model. Proc Natl Acad Sci USA 99: 2344-2349.

CARON, H., VAN SLUIS, P., VAN HOEVE, M., DE KRAKER, J., BRAS, J., SLATER R., MANNENS, M., VOUTE, P.A., WESTERVELD, A. and VERSTEEG, R. (1993). Allelic loss of chromosome 1p36 in neuroblastoma is of preferentia maternal origin and correlates with N-myc amplification. Nat Genet4: 187-190.

CATTANACH, B.M. and KIRK, M. (1985). Differential activity of maternally and paternally derived chromosome regions in mice. Nature 315: 496-498.

CHIBA, S., LEE, Y.M., ZHOU, W. and FREED, C.R. (2008). Noggin enhances dopamine neuron production from human embryonic stem cells and improves behavioral outcome after transplantation into Parkinsonian rats. Stem Cells 26: 2810-2820.

CHIN, M.H., MASON, M.J., XIE, W., VOLINIA, S., SINGER, M., PETERSON, C., AMBARTSUMYAN, G., AIMIUWU, O., RICHTER, L., ZHANG, J. et al. (2009). Induced pluripotent stem cells and embryonic stem cells are distinguished by gene expression signatures. Cel/ Stem Cel/5: 111-123.

CIBELLI, J.B., GRANT, K.A., CHAPMAN, K.B., CUNNIFF, K., WORST, T., GREEN, H.L., WALKER, S.J., GUTIN, P.H., VILNER, L., TABAR, V. et al. (2002) Parthenogenetic stem cells in nonhuman primates. Science 295: 819.

DEIERBORG, T., SOULET, D., ROYBON, L., HALL, V. and BRUNDIN, P. (2008) Emerging restorative treatments for Parkinson's disease. Prog Neurobio/ 85 : 407-432.

DENG, J., SHOEMAKER, R., XIE, B., GORE, A., LEPROUST, E.M., ANTOSIEWICZBOURGET, J., EGLI, D., MAHERALI, N., PARK, I.H., YU, J. et al. (2009). Targeted bisulfite sequencing reveals changes in DNA methylation associated with nuclear reprogramming. Nat Biotechno/27: 353-360.

DINGER, T.C., ECKARDT, S., CHOI, S.W., CAMARERO, G., KUROSAKA, S., HORNICH, V., MCLAUGHLIN, K.J. and MULLER, A.M. (2008). Androgenetic embryonic stem cells form neural progenitor cells in vivoand in vitro. Stem Cells 26: $1474-1483$.

DOI, A., PARK, I.H., WEN, B., MURAKAMI, P., ARYEE, M.J., IRIZARRY, R., HERB, B., LADD-ACOSTA, C., RHO, J., LOEWER, S. et al. (2009). Differential methylation of tissue- and cancer-specific $\mathrm{CpG}$ island shores distinguishes human induced pluripotent stem cells, embryonic stem cells and fibroblasts. Nat Genet 41: 1350-1353.

DRAPER, J.S. and NAGY, A. (2007). Improved embryonic stem cell technologies Handb Exp Pharmacol. pp. 107-128.

ECKARDT, S., DINGER, T.C., KUROSAKA, S., LEU, N.A., MULLER, A.M. and MCLAUGHLIN, K.J. (2008). In vivo and in vitro differentiation of uniparental embryonic stem cells into hematopoietic and neural cell types. Organogenesis 4: 33-41. 
ECKARDT, S., LEU, N.A., BRADLEY, H.L., KATO, H., BUNTING, K.D. and MCLAUGHLIN, K.J. (2007). Hematopoietic reconstitution with androgenetic and gynogenetic stem cells. Genes Dev21: 409-419.

FREED, W.J., CHEN, J., BACKMAN, C.M., SCHWARTZ, C.M., VAZIN, T., CAI, J., SPIVAK, C.E., LUPICA, C.R., RAO, M.S. and ZENG, X. (2008). Gene expression profile of neuronal progenitor cells derived from hESCs: activation of chromosome $11 \mathrm{p} 15.5$ and comparison to human dopaminergic neurons. PLOS One 3: e1422.

FUNDELE, R., NORRIS, M.L., BARTON, S.C., REIK, W. and SURANI, M.A. (1989). Systematic elimination of parthenogenetic cells in mouse chimeras. Development 106: 29-35.

HEDLUND, E. and PERLMANN, T. (2009). Neuronal cell replacement in Parkinson's disease. J Intern Med266: 358-371.

HERMANN, A., MAISEL, M., LIEBAU, S., GERLACH, M., KLEGER, A., SCHWARZ, J., KIM, K.S., ANTONIADIS, G., LERCHE, H. and STORCH, A. (2006). Mesodermal cell types induce neurogenesis from adult human hippocampal progenitor cells. J Neurochem 98: 629-640.

HERNANDEZ, L., KOZLOV, S., PIRAS, G. and STEWART, C.L. (2003). Paternal and maternal genomes confer opposite effects on proliferation, cell-cycle length, senescence, and tumor formation. Proc Nat/Acad Sci USA 100: 1334413349.

HU, B.Y., WEICK, J.P., YU, J., MA, L.X., ZHANG, X.Q., THOMSON, J.A. and ZHANG, S.C. (2010). Neural differentiation of human induced pluripotent stem cells follows developmental principles but with variable potency. ProcNat/Acad Sci USA 107: 4335-4340.

JANKOVIC, J. (2008). Parkinson's disease: clinical features and diagnosis. J Neurol Neurosurg Psychiatry 79: 368-376.

KATZ, F., WEBB, D., GIBBONS, B., REEVES, B., MCMAHON, C., CHESSELLS, J. and MITCHELL, C. (1992). Possible evidence for genomic imprinting in childhood acute myeloblastic leukaemia associated with monosomy for chromosome 7. Br J Haemato/80: 332-326.

KAWASAKI, H., MIZUSEKI, K., NISHIKAWA, S., KANEKO, S., KUWANA, Y., NAKANISHI, S., NISHIKAWA, S.I. and SASAI, Y. (2000). Induction of midbrain dopaminergic neurons from ES cells by stromal cell-derived inducing activity. Neuron 28: 31-40.

KEVERNE, E.B., FUNDELE, R., NARASIMHA, M., BARTON, S.C. and SURANI, M.A. (1996). Genomic imprinting and the differential roles of parental genomes in brain development. Brain Res Dev Brain Res 92: 91-100.

KIM, J.H., AUERBACH, J.M., RODRIGUEZ-GOMEZ, J.A., VELASCO, I., GAVIN, D., LUMELSKY, N., LEE, S.H., NGUYEN, J., SANCHEZ-PERNAUTE, R. BANKIEWICZ, K. et al. (2002). Dopamine neurons derived from embryonic stem cells function in an animal model of Parkinson's disease. Nature 418: 5056.

LENGERKE, C., KIM, K., LEROU, P. and DALEY, G.Q. (2007). Differentiation potential of histocompatible parthenogenetic embryonic stem cells. Ann $N Y$ Acad Sci1106: 209-218.

LINDVALL, O. and KOKAIA, Z. (2009). Prospects of stem cell therapy for replacing dopamine neurons in Parkinson's disease. Trends Pharmacol Sci30: 260-267.

MANN, J.R., GADI, I., HARBISON, M.L., ABBONDANZO, S.J. and STEWART, C.L. (1990). Androgenetic mouse embryonic stem cells are pluripotent and cause skeletal defects in chimeras: implications for genetic imprinting. Ce//62: 251 260.

MAXWELL, S.L. and LI, M. (2005). Midbrain dopaminergic development in vivoand in vitro from embryonic stem cells. J Anat 207: 209-218.

MCGRATH, J. and SOLTER, D. (1984). Completion of mouse embryogenesis requires both the maternal and paternal genomes. Ce//37: 179-183.

MENENDEZ, P., WANG, L. and BHATIA, M. (2005). Genetic manipulation of human embryonic stem cells: a system to study early human development and potential therapeutic applications. Curr Gene Ther5: 375-385.

NARASIMHA, M., BARTON, S.C. and SURANI, M.A. (1997). The role of the paternal genome in the development of the mouse germ line. Curr Bio/7: 881884.

NISHIKAWA, S., OGAWA, M., KUNISADA, T. and KODAMA, H. (1988). B lymphopoiesis on stromal cell clone: stromal cell clones acting on different stages of B cell differentiation. Eur J Immuno/ 18: 1767-1771.

OKABE, S., FORSBERG-NILSSON, K., SPIRO, A.C., SEGAL, M. and MCKAY, R.D. (1996). Development of neuronal precursor cells and functional postmitotic neurons from embryonic stem cells in vitro. Mech Dev 59: 89-102.

OLANOW, C.W. and TATTON, W.G. (1999). Etiology and pathogenesis of Parkinson's disease. Annu Rev Neurosci22: 123-144.

PARISH, C.L. and ARENAS, E. (2007). Stem-cell-based strategies for the treatment of Parkinson's disease. Neurodegener Dis 4: 339-347.

PRELLE, K., ZINK, N. and WOLF, E. (2002). Pluripotent stem cells-model of embryonic development, tool for gene targeting, and basis of cell therapy. Anat Histol Embryo/31: 169-186.

REVAZOVA, E.S., TUROVETS, N.A., KOCHETKOVA, O.D., KINDAROVA, L.B., KUZMICHEV, L.N., JANUS, J.D. and PRYZHKOVA, M.V. (2007). Patientspecific stem cell lines derived from human parthenogenetic blastocysts. Cloning Stem Cells 9: 432-449.

ROBERTSON EJ, K.M., BRADLEY A, EVANS MJ. (1983). Isolation, properties, and karyotype analysis of pluripotential (EK) cell lines from normal and parthenogenetic embryos. In Teratocarcinomal Stem Cells Cold Spring Harbor Conferences on Cell Proliferation (Silver LM, Martin GR, Strickland S), Cold Spring Harbor Laboratory, New York, pp. 647-663.

RODRIGUEZ-GOMEZ, J.A., LU, J.Q., VELASCO, I., RIVERA, S., ZOGHBI, S.S., LIOW, J.S., MUSACHIO, J.L., CHIN, F.T., TOYAMA, H., SEIDEL, J. et al. (2007). Persistent dopamine functions of neurons derived from embryonic stem cells in a rodent model of Parkinson disease. Stem Cel/s 25: 918-928.

SANCHEZ-PERNAUTE, R., LEE, H., PATTERSON, M., RESKE-NIELSEN, C. YOSHIZAKI, T., SONNTAG, K.C., STUDER, L. and ISACSON, O. (2008). Parthenogenetic dopamine neurons from primate embryonic stem cells restore function in experimental Parkinson's disease. Brain 131: 2127-2139.

SASAI, Y. (2002). Generation of dopaminergic neurons from embryonic stem cells. $J$ Neuro/249 Suppl 2: 1141-1144.

SATO, S., YAGI, S., ARAI, Y., HIRABAYASHI, K., HATTORI, N., IWATANI, M. OKITA, K., OHGANE, J., TANAKA, S., WAKAYAMA, T. et al. (2010). Genomewide DNA methylation profile of tissue-dependent and differentially methylated regions (T-DMRs) residing in mouse pluripotent stem cells. Genes Cel/s 15 607-618.

SCRABle, H., CAVENEE, W., GHAVIMI, F., LOVELL, M., MORGAN, K. and SAPIENZA, C. (1989). A model for embryonal rhabdomyosarcoma tumorigenesis that involves genome imprinting. Proc Nat/ Acad Sci USA 86: 7480-7484.

SOLTER, D. (2006). Imprinting today: end of the beginning or beginning of the end? Cytogenet Genome Res 113: 12-16.

STURM, K.S., FLANNERY, M.L. and PEDERSEN, R.A. (1994). Abnormal development of embryonic and extraembryonic cell lineages in parthenogenetic mouse embryos. Dev Dyn 201: 11-28.

SURANI, M.A., BARTON, S.C. and NORRIS, M.L. (1984). Development of reconstituted mouse eggs suggests imprinting of the genome during gametogenesis. Nature 308: 548-550.

TAKAGI, Y., TAKAHASHI, J., SAIKI, H., MORIZANE, A., HAYASHI, T., KISHI, Y., FUKUDA, H., OKAMOTO, Y., KOYANAGI, M., IDEGUCHI, M. et al. (2005). Dopaminergic neurons generated from monkey embryonic stem cells function in a Parkinson primate model. J Clin Invest 115: 102-109.

TERAMURA, T., ONODERA, Y., MURAKAMI, H., ITO, S., MIHARA, T., TAKEHARA T., KATO, H., MITANI, T., ANZAI, M., MATSUMOTO, K. et al. (2009). Mouse androgenetic embryonic stem cells differentiated to multiple cell lineages in three embryonic germ layers in vitro. J Reprod Dev 55: 283-292.

TORIUMI, H., YOSHIKAWA, M., MATSUDA, R., NISHIMURA, F., YAMADA, S. HIRABAYASHI, H., NAKASE, H., NONAKA, J., OUJI, Y., ISHIZAKA, S. et al. (2009). Treatment of Parkinson's disease model mice with allogeneic embryonic stem cells: necessity of immunosuppressive treatment for sustained improvement. Neurol Res 31: 220-227.

VIERBUCHEN, T., OSTERMEIER, A., PANG, Z.P., KOKUBU, Y., SUDHOF, T.C. and WERNIG, M. (2010). Direct conversion of fibroblasts to functional neurons by defined factors. Nature 463: 1035-1041.

WILKINSON, L.S., DAVIES, W. and ISLES, A.R. (2007). Genomic imprinting effects on brain development and function. Nat Rev Neurosci 8: 832-843.

YAMANAKA, S. (2007). Strategies and new developments in the generation of patient-specific pluripotent stem cells. Cell Stem Cel/1: 39-49.

YANG, D., ZHANG, Z.J., OLDENBURG, M., AYALA, M. and ZHANG, S.C. (2008). Human embryonic stem cell-derived dopaminergic neurons reverse functional deficit in parkinsonian rats. Stem Cells 26: 55-63. 


\section{Further Related Reading, published previously in the Int. J. Dev. Biol.}

See our recent Special Issue Developmental Hematopoiesis

edited by Charles Durand, Tierry Jaffredo and Alexander Medvinsky at:

http://www.ijdb.ehu.es/web/contents.php?vol=54\&issue=6-7

Neurogenic differentiation of human conjunctiva mesenchymal stem cells on a nanofibrous scaffold Masoud Soleimani, Samad Nadri, Iman Shabani

Int. J. Dev. Biol. (2010) 54: 1295-1300

Otx2 expression is restricted to dopaminergic neurons of the ventral tegmental area in the adult brain Michela Di Salvio, Luca G. Di Giovannantonio, Daniela Omodei, Dario Acampora and Antonio Simeone Int. J. Dev. Biol. (2010) 54: 939-945

Serotonin involvement in the metamorphosis of the hydroid Eudendrium racemosum Giuliana Zega, Roberta Pennati, Arianna Fanzago and Fiorenza De Bernardi

Int. J. Dev. Biol. (2007) 51: 307-313

D-4 and D-1/D-5 dopamine receptors interact synergistically in the rat striatum S Trias, A Rivera, M Megias, A Penafiel, F Marin-Giron, A De la Calle

Int. J. Dev. Biol. (2001) 45: S93-S94

The eyeless mutant gene (e) in the Mexican axolotl (Ambystoma mexicanum) affects pax-6 expression and forebrain axonogenesis. G W Eagleson, L M Gerlach and T A Platz

Int. J. Dev. Biol. (2001) 45: 653-660

The role of stem cell factor and of alternative c-kit gene products in the establishment, maintenance and function of germ cells. C Sette, S Dolci, R Geremia and P Rossi

Int. J. Dev. Biol. (2000) 44: 599-608

Genetic and epigenetic control of midbrain dopaminergic neuron development.

C Perrone-Capano and U Di Porzio

Int. J. Dev. Biol. (2000) 44: 679-687

Dopamine in the developing kidney.

$\mathrm{J}$ Svennilson and A Aperia

Int. J. Dev. Biol. (1999) 43: 441-443

Myogenesis in cultures of uniparental mouse embryonic stem cells: differing patterns of expression of myogenic regulatory factors. L A McKarney, M L Overall and M Dziadek

Int. J. Dev. Biol. (1997) 41: 485-490

5 yr ISI Impact Factor $(2008)=3.271$

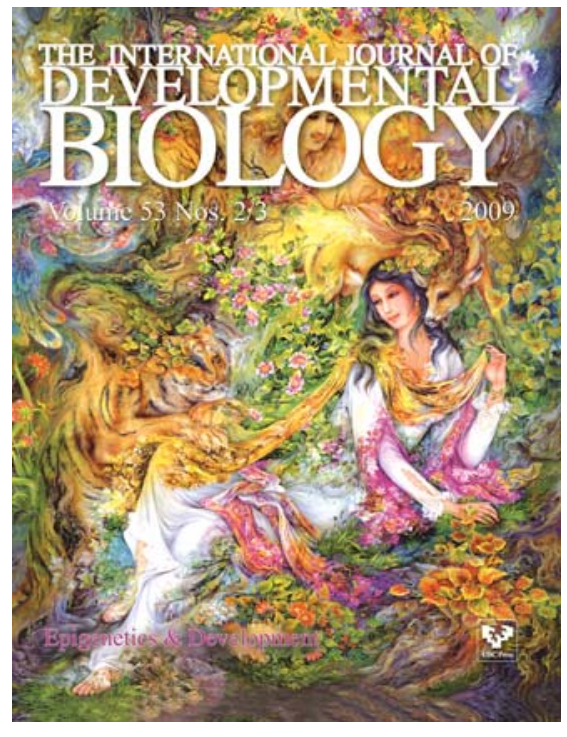

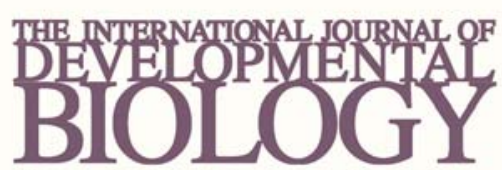

Volume 54 Nos. 6/7
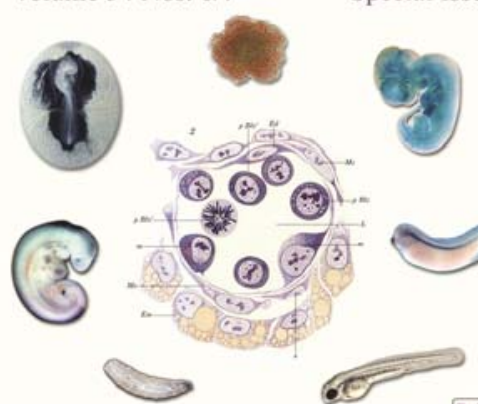

Developmental Hematopoiesis

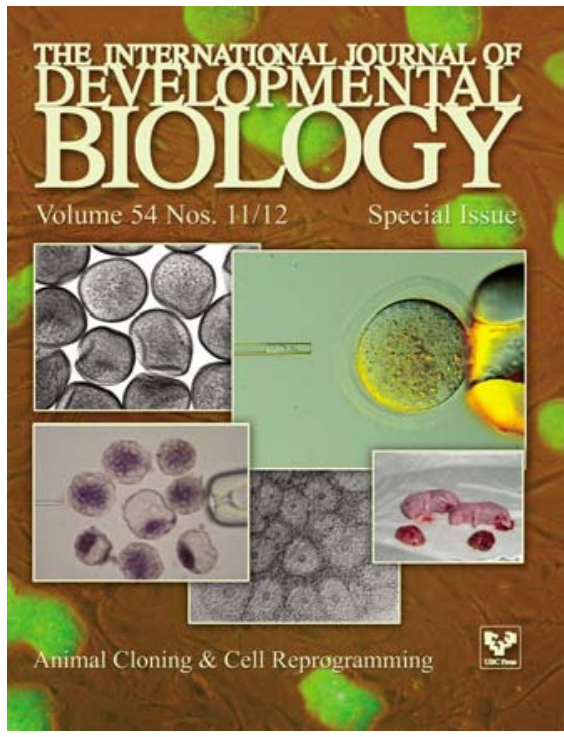

